Галина Лукић

Технички факултет у Зрењанину

Катедра за основне и примењене науке galja.lukic@gmail.com
УДК 821.161.1-3.09

https://doi.org/10.18485/slavistika.2021.25.1.22

Оригинални научни рад примљено 14.02.2021.

прихваћено за штампу 17.06.2021.

\title{
СИМБОЛИЧКИ ДЕТАљИ У ПОЈЕДИНИМ ПРИПОВЕТКАМА А. П. ЧЕХОВА
}

Средства уметничког изражавања имају изузетан значај у Чеховљевој поетици. У датом раду на примеру приповедака „Три године“, „Ротшилдова виолина“, „Професор књижевности“, „Мој живот“, „У родном дому“, „Убиство“, „Прича непознатог човека“, „Непријатност“" хтели смо да размотримо особености симболичких детаља. У стварању индивидуално-ауторских симбола манифестује се оригиналност пишчевог књижевног стила. Асоцијативна слика јавља се обично као резултат неочекиваног споја различитих појмова. Чеховљеве симболичке детаље карактерише неутралност, они могу настати од предмета као што су кишобран, врба, виолина и чак плави материјал. Свакодневни предмети у Чеховљевом уметничком систему потпуно неочекивано испуњавају се дубоким идејним смислом и појављују се пред читаоцем у својој вишој манифестацији. Индивидуални ауторски симбол увек садржи високи степен уметничке информативности, јер изводи реч (предмет) из аутоматизма доживљаја. Да би се што потпуније објаснио смисао симболичког детаља, потребно је пажљиво пратити његово композиционо укључивање у текст приповедања: са чим је повезано појављивање неког детаља, какве га емоције прате, каквим се новим смислом испуњава у свакој новој епизоди.

Кључне речи: Чехов, симбол, симболички детаљ, асоцијативна слика.

The means of artistic expressiveness have an enormous significance in Chekhov's poetics. In this paper, on the examples of short stories such as "Three Years", "Rothschild's Violin", "Literature Teacher", etc. we examined the uniqueness of Chekhov's symbolic details. The author's creation of individual symbols expresses originality of his prose style. An associative image usually appears as the result of unexpected compound of different notions. Chekhov's symbolic details are characterised by neutrality, they can evolve from plain objects such as an umbrella, a willow, a violin and even a piece of a blue cloth. Everyday objects in Chekhov's artistics system quite unexpectedly acquire profound sensical meaning and appear before the reader in its higher manifestation. The author's individual symbol always contains a high level of information because it transforms our experience of the word's (the object's) common meaning. In order to explain the meaning of the symbolic detail as clearly as possible, it is necessary to follow a compositional inclusion into the narrative - what the appearance of every new detail relates to, what the emotions that accompany it are, what its new ascribed meaning in each and every new episode is.

Keywords: Chekhov, symbol, symbolic details, associative image.

У чланку „Чехов“ Андреј Бели пише: „Чехов никада себе није сматрао за симболисту, међутим он као да је племенито и искрено настојао да све своје стваралаштво посвети томе да оно постане темељ рускога симболизма“ (Белый 2002: 833). ${ }^{1}$ Приказујући своје јунаке у различитим животним ситуацијама,

\footnotetext{
${ }^{1}$ «Чехов никогда не сознавал себя символистом, но он благородно и честно как бы отдал все свое творчество на то, чтобы творчество его стало подножием русского символизма». Превод цитиране литературе и Чеховљевих текстова из приповедака у даљем тексту Г. Лукић.
} 
писац разоткрива сваку од њих са њему својственом једноставношћу, помоћу најобичнијих предмета свакодневне употребе. Мајсторство А. П. Чехова манифестује се у томе што управо овај предмет свакодневне употребе неочекивано постаје код њега својеврсни симбол који садржи одређену идеју. А. П. Чудаков, наглашавајући својеврсност чеховских симбола, пише: „За симболе он не узима неке 'специјалне' предмете, који могу бити знак скривеног 'другог плана', већ по своме утврђеном или лако препознатљивом значењу. У овом својству појављују се обични предмети свакодневице“ (Чудаков 1971: 167). Заиста, у Чеховљевим приповеткама симбол може постати било који предмет: и кишобран, и виолина, и чак кувани кромпир. Денотативно значење речи, која назива или описује предмет, шири и компликује своју семантику у текстуалном пространству дела. Такав симболички детаљ помаже да се открије скривени смисао дела, пошто веома често постаје идејно-смисаона доминанта дела.

Ј. Лотман је сматрао да је основно предодређење симбола - „реално представљати свет надпостојања на нивоу постојања“ (Лотман 1992: 193). Приликом анализе симболичких детаља у Чеховљевим приповеткама, ослањали смо се на концепцију симбола А. Лосјева. Тумачећи грчко порекло термина симбол, филозоф каже да етимологија речи symbolon и symballo „указује на поклапање два плана стварности, те управо на то, да симбол има значење не сам по себи, већ као арена сусрета познатих конструкција сазнања са неким другим могућим предметом овог сазнања“ (Лосев 1995: 8). Карактеристична црта појма симбол, по мишљењу филозофа, јесте „моделно и законито, систематско разлагање неке уопштене функције стварности у бесконачни низ појединости и посебности“ (Лосев 1995: 11). Свој, такозвани нови „израз““, симболички детаљ (пошто је то нека ствар или предмет), показује приликом сваког свог понављања у току приповедања, разоткривајући нове нијансе свог идејног садржаја.

Да би се што потпуније разоткрио смисао симболичког детаља, потребно је пажљиво пратити у каквој епизоди, у каквом делу приповетке се он појављује, са чиме је ово повезано и какве га емоције прате. Разматрање нашег питања ограничили смо на материјал прозних радова, почев од краја осамдесетих година 19. века до 1903. године. Традиционално се Чеховљево стваралаштво дели на три периода. ${ }^{2}$ Први период (1880-1888) карактеришу кратке хумористичке приповетке, други период (1888-1899) је такозвани „преломни период“ стваралаштва, када Чехов пише велике новеле и приче, и трећи период (1899-1904) - период драматургије. Ова подела је наравно условна, јер је у последњем периоду Чехов такође писао и новеле. О каснијим Чеховљевим приповеткама Д. П. Мирски пише: „1886. године (...) Чехов се ослобађа терета хумористичких часописа и уводи свој сопствени стил, који се назирао и раније“ (Мирский 2006). На следећи начин карактерише други период стваралаштва Ј. Замјатин: „И тек у другој половини осамдесетих година дешава се у њему нагла промена, тек тада се он први пут озбиљно замислио над животом, над смислом живота, над смрћу. Први пут у томе што он пише, јавља се оштри укус горчине, туге, незадовољства“ (Замятин 1955: 42). На тај начин овај период пишчевог ствара-

\footnotetext{
2 Детаљније о хронолошким границама између периода Чеховљевог стваралаштва види у Громов 1958 .
} 
лаштва представља се као дубљи и свеснији, и према томе интересантнији за нашу анализу.

У приповеци „Три године“ (Три года) заљубљени Лаптев, нашавши кишобран који је заборавила Јулија Сергејевна, доживљава навалу силних емоција, чак среће: „У кући је угледао на столици кишобран који је заборавила Јулија Сергејевна, зграбио га је и страсно пољубио. Кишобран је био свилен, помало похабан, везан старом гумицом; дршка је била обична,од беле кости, јефтина. Лаптев га је раширио изнад себе и чак му се учинило да све око њега мирише на срећу“ (Чехов 1977, IX: 15). Реакција коју је изазвала код Лаптева ствар вољене жене (,зграбио“, „страсно пољубио“) говори о снази његових осећања према Јулији Сергејевној. И кишобран је у стању да усрећи ако припада вољеној жени. Како примећује А. Белкин, „кишобран постаје уметнички детаљ, кроз који се открива осећање Лаптева. (...). Нашу пажњу привлачи необична метафора 'мирише на срећу'“ (Белкин 1973: 222).

Следећи пут се кишобран спомиње у преломном моменту Лаптевљевог живота, када се у његовом и Јулијином брачном животу одиграло много различитих догађаја. Лаптев се налази на прагу нове етапе; нове обавезе и нова улога наследника великог капитала њега плаше и оптерећују. У будућности, како му се чини, нема ничег светлог: „, -Како год било, треба се поздравити са мислима о срећи... “, - говори он жени. И у том тренутку он се одједном сећа кишобрана и тог момента усхићења и среће, који је он у њему некад давно изазвао: „Узео га је и дао жени. (...) Јулија се на тренутак загледала у кишобран, препознала га и тужно се осмехнула. (...). - Ако је могуће, молим те, врати се раније. Без тебе ми је досадно“ (Чехов 1977, IX: 86). Ова молба Јулије Сергејевне звучи као изјава љубави своме мужу, који је за дуге године њиховог заједничког живота већ изгубио наду да му жена узврати осећања. И ево сада, овај кишобран поново је сведок љубави коју је тако дуго чекао Лаптев. Када је Лаптев отишао, Јулија Сергејевна је „дуго посматрала кишобран“, као да гледа другим очима све оно што је било с њим повезано. Пружајујући жени кишобран, Лаптев јој заједно с њим поклања своју љубав. Управо у датој епизоди новеле Јулија Сергејевна напокон постаје свесна да заправо воли свога мужа.

Кишобран се појављује још једном, на крају приповетке, у фрагменту који је посвећен опису узајамних односа Лаптева и његове жене, пратећи те нове емоције, које је открила у себи Јулија Сергејевна: „На њој је била лагана елегантна хаљина, опшивена чипком, хаљина крем светле боје, а у рукама је био тај исти стари познати кишобран““ (Чехов 1977, IX: 90). Откривши за себе ово осећање, она га брижно носи у себи (са собом, као кишобран). Ово је тај исти Лаптев, њен муж, али је он сада за њу другачији, драг је њој и вољен: „,- Знаш, волим те, - рекла је и поцрвенела. - Ти ми значиш“ (Чехов 1977, IX: 90). На тај начин кишобран у овој приповеци постаје симбол љубави, симбол интензивног осећања које се родило у Лаптеву а после извесног времена са новом снагом рефлектује се у Јулији Сергејевној. Наведени пример појашњава следеће запажање Лотмана: „Даљи развој сижеа јесте само разоткривање могућности које су скривене у симболу“ (Лотман 1996: 145).

Детаљи, распоређени по целом тексту, јесу нити које повезују не само текст, већ и подтекст, сакривен иза спољашњег садржаја. Понављајући се у тексту, детаљ 
се сваки пут надограђује допунским смислом, игра значајну улогу у формирању симбола, који расветљава кључне моменте сижеа. И. Г. Минералова, говорећи о симболичким детаљима у Чеховљевим делима, подвлачи значај њихових композицијских понављања: „У његовим делима, слично поетском стваралаштву, присуствује сложени систем композицијских понављања. (...) У Чеховљевој прози је развијен принцип регуларног понављања одређених детаља садржаја“ (Минералова 1985: 8). По мишљењу Минералове, управо ова понављања рађају сложене подтекстне асоцијације, повезане са семантиком симболичких детаља: „(...) систем асоцијација који се рађа из поновљеног детаља је неупоредиво значајнији него неки од ових детаља (ако би се оцењивали иманентно)“ (Минералова 1985: 9).

Симбол је вишезначан и та вишезначност подстиче читаоца на активну рецепцију. Своје тумачење симбол добија у процесу узајамног односа са елементима приповедања који га окружују, у свакој епизоди разоткривајући свој нови значај. Јежи Фарино (Jerzy Faryno) каже: „... с и м б о л - то је појмовни систем, сажет (или: редукован) до једног елемента који поседује статус реалног објекта; Статус 'јединице појмовног система' објашњава, зашто се са представом симбола повезује и представа контекста; нешто не може бити знак, уколико је појединачно и не улази у одређену мрежу односа са другим знацима“" (Фарыно 2004: 90-91). Стога приликом анализе текста пожељно је оријентисати се на унутрашњи контекст који нас упућује на симболичку природу неког објекта.

У приповеци „Мој живот“ (Моя жизнь) детаљ „штаке“, како се овде назива потпорна конструкција за зидове, симболише обогаљен и несређен живот Мисаила и његове сестре. Њихов отац је ограничавао своју децу у свему: у храни, у комуникацији, у избору свог животног пута, што их је учинило веома несрећним људима који нису могли да се остваре кроз живот.

Мисаил чак не живи у очевој кући, већ у помоћној просторији, у чије зидове су „забијене велике штаке“. И у почетку и на крају новеле, ове штаке су описане скоро исто: „Као у инат, у мојој лампи изгорео је већ сав петролеј, она се пушила, спремала се да се угаси и старе штаке на зидовима гледале су сурово, и њихова сенка је треперила“ (Чехов 1977, IX: 199). И на крају приповедања, када Мисаил покушава да се помири са оцем, он долази у своју собицу: „Штаке на зидовима су гледале као и пре, и њихове сенке су трепериле. Било је хладно“ (Чехов 1977, IX: 275). То јест, све је остало као и пре: однос са оцем се неће поправити, он ће остати исто тако „суров“ према своме сину, као и пре. Мисаил му на крају у лице истреса сву истину о његовом јадном животу и тиранији: „,...али због чега тај ваш живот, који ви сматрате обавезним и за нас, - зашто је он тако досадан, тако јадан, зашто ни у једној од тих зграда, које ви градите већ скоро тридесет година, нема људи, од којих бих ја могао да научим како да живим, а да се не осећам кривим?“(Чехов 1977, IX: 278).

Симбол ствари јесте формирање „идејно-сликовитог“ грађења ствари. Притом, да би идејна сликовитост могла постати симбол, дужна је „да указује на нешто друго, што није она сама, и чак да буде за те друге предмете закон њихове градње“ (Лосев 1995: 26). Стога видимо да су штаке концентрисале у себи главну идеју нарације коју Мисаил исказује своме оцу. 
У приповеци „У родном дому“ (В родном углу) слика степе постаје симбол начина живота којем Вера у почетку покушава да се супротстави, али на крају крајева мораће да се потчини. Јунакиња, прилазећи дому, ужива у призору степе: „Степа, степа - и више ништа; у даљини се види стара хумка или ветрењача; воловима превозе камени угаљ... Птице усамљено, ниско надлећу равницу, и равномерни покрети њихових крила терају у дремеж. Прошло је сат-два, а свугде је степа, степа, и све је хумка у даљини“"(Чехов 1977, IX: 313).

Дати опис степе првенствено производи утисак бескрајне једноличности, досадног и монотоног живота, који очекује Веру на њеном имању, иако младој девојци призор степе пружа осећање слободе и пространства: „Вера се такође предала заносу степе, заборавила је на прошлост и мислила је само о томе како овде има пуно простора, како је слободно; ...“(Чехов 1977, IX: 313). Већ другог дана свог боравка на имању, Вера, шетајући у врту, схвата: „Овај простор, овај лепи степски спокој говорили су јој да је срећа близу и већ је ту; ...И у исто време бесконачна равница, једнообразна, без иједне живе душе, плашила је, и на тренутке јој је било јасно да ће ово спокојно зелено чудовиште прогутати њен живот, претворити га у ништа“" (Чехов 1977, IX: 316).

Сада се степа већ чини Вери као „зелено чудовиште“. На самом крају приповетке, Вера се ипак покорава својој судбини, схвата да је борба бескорисна, па чак и немогућа: „, Не треба живети, треба се стопити у једно са овом раскошном степом, безграничном и равнодушном као вечност, са њеним цвећем, хумкама и даљином, и тада ће све бити добро...“ (Чехов 1977, IX: 324). Овде застрашује констатација да „не треба живети него се стопити у једно“. Вера одлучује да не живи, већ да се покори.

У „Професору књижевности“ (Учитель словесности), у епизоди у којој Никитин изјављује љубав Мањусји, три пута се спомиње детаљ - „плава тканина“. Никитин чека Мањусју да јој каже главне речи: „...утрчала је Мањусја у тамној хаљини, са комадом плаве тканине у рукама, и не примећујући Никитина, трчећи, се попела уз степенице“ (Чехов 1977, VIII: 321). Даље, када он почиње разговор са Мањусјом: „Задихао се, није знао шта да каже; једном руком је држао њену руку, а другом - плаву тканину“. Затим, напокон, „плава тканина је пала на под и Никитин је узео Мањусју за другу руку““(Чехов 1977, VIII: 321). Троструко помињање „плаве тканине“ у овој краткој епизоди, наравно, има свој скривени смисао. Плава тканина, као што ћемо видети на крају приповетке, симболише Мањусјину малограђанску природу, њен ситничарски, штедљиви однос према животу, а такође сиву монотоност провинцијског начина живота. Држећи се једном руком за плаву тканину, Никитин као да се придружује Мањусјином свету прихватајући његову суштину и правила. Важан је такође опис места где се догађа изјава љубави. Збуњена Мањусја „кад је устукнула пред Никитином, нашла се у углу између зида и ормара“" (Чехов 1977, VIII: 321). Затим читамо: „Она је забацила главу уназад, а он ју је пољубио у уста и да би овај пољубац трајао дуже, узео је њене образе прстима; и некако је испало да се он сам нашао у углу између ормара и зида, а она је обгрлила његов врат...“ (Чехов 1977, VIII: 321). Простор, „угао између зида и ормара“, где је прво била Мањусја, означава њен затворен, ограничен свет, у који упада Никитин оженивши се њоме, зато што „некако је испало, да се он сам нашао у углу између ормара и зида“ 
(Чехов 1977, VIII: 321). Овај просторни детаљ само допуњује значење симболичког детаља „плаве тканине“. Његово потпуно идејно разоткривање видимо на крају приповетке, када разочаран својим породичним животом са Мањусјом, Никитин вришти у себи и пише у дневнику: „Где сам то ја, Боже мој?! Мене окружује баналност и баналност. Досадни, ништавни људи, теглице са павлаком, бокали са млеком, бубе, глупе жене..." (Чехов 1977, VIII: 322).

У „Ротшилдовој виолини“ (Скрипка Ротиильда) виолина је оваплоћење тог светлог зрака, слабашног душевног жара у очврснутој Јаковљевој души, она је оно вредно и светло што је остало у Јаковљевом животу, његова једина утеха: „...спустио би поред себе на кревет виолину и када би му се свакаква глупост мотала по глави, додиривао је жице, виолина је одзвањала у мраку и њему би постало лакше“ (Чехов 1977, VIII: 298). Код Јакова као да се одиграва дијалог са виолином. Унутрашњи зрак светлости, драгоцена честица Јаковљеве душе оваплоћује се у материјалном свету у облику виолине, коју он доживљава као живо биће, и то беспомоћно и незаштићено: „Није му било жао да умре, али чим би у кући спазио виолину, срце би му се стегло и постало би му жао“; „Јаков је изашао из куће и сео на праг стежући на грудима виолину“ (Чехов 1977, VIII: 304). Умирући, Јаков завештава да се његова виолина да Јеврејину Ротшилду, којег за живота није волео. Таква Јаковљева одлука се објашњава епизодом на крају приповетке. Када је Јаков свирао на виолини Ротшилду, овај се расплакао од умиљења и усхићења, што говори о његовој истанчаној души. Он је такође дубоко проживљавао звуке виолине, као и Јаков. Тако Јаков предаје достојном чувару ту светлу и чисту искрицу своје душе, која ће остати да гори и после његове смрти. Пред нама је предмет материјалног света - виолина. Међутим, њена смисаона пуноћа, коју видимо у новели (Јаковљев однос према њој, њен психо-емоционални утицај на њега), претвара је у слику, која постаје симбол. Симбол, усмерен према осећањима, рађа сложене асоцијације.

Још један симболички детаљ у датој приповеци јесте оваплоћен у слици врбе. Јаковљева жена, налазећи се на самрти, сећа се најсветлијих момената свога живота: „Сећаш се, пре педесет година Бог нам је дао детенце са плавом косицом? Нас двоје смо тада стално седели крај реке и певали песме... испод врбе“ (Чехов 1977, VIII: 301). Реч „врба“ је чак интерпункцијски одвојена са три тачке, као закључак свега реченог, као оно што је упило у себе сав смисао реченог. Међутим, Јаков се апсолутно ничега не сећа. Тек после женине сахране, он је отишао изван града и неочекивано препознао исту врбу: „А ево широка стара врба са огромном дупљом, а на њој су вране свиле гнезда...“ (Чехов 1977, VIII: 303). Поново три тачке, које нас нагоне да се зауставимо, да се удубимо у речено. Врба је остарила, у њој се створила велика дупља, па је ни вранина гнезда не чине привлачнијом. „И одједном се у Јаковљевом сећању јасно јавили детенце са плавом косицом и врба о којој је говорила Марта. Да, то је иста врба - зелена, тиха, тужна... Како је она остарела, јадна!“ (Чехов 1977, VIII: 303). Врба овде, са једне стране, симболише ту породичну срећу, која је тако брзо пролетела у Мартином животу, с друге стране, оваплоћује слику младе Марте, која се радовала животу, своме детету и мужу. Марта је умрла, а у врби се створила огромна дупља, као да су из ње ишчупали срце. Како примећује Лосјев: „(...) поседујући симбол ствари, ми...поседујемо бесконачан број разних одраза, или израза ства- 
ри, који су у стању да изразе ову ствар са различитом прецизношћу...“ (Лосев 1995: 9).

У наведеним примерима смо видели како се симболички детаљ, спомињући се неколико пута у новели, постепено приводи ка схватању његовог идејносадржајног смисла. Приликом првог помињања, он се још не доживљава као симбол, своју симболичку функцију стиче постепено, посредством специфичних смисаоних веза са другим елементима уметничког приповедања. То је особина лајтмотивских симболичких детаља који, испуњавајући се дубљим смислом, садрже у себи богати спектар манифестација емоционалног плана, откривајући идејну суштину приповедања на нивоу подтекста.

У неким приповеткама срећемо се са таквим детаљима-симболима, који одмах дају карактеристику ситуације. Пошто се пројави у некој епизоди, он у оквирима идејног контекста и веза са другим компонентама текста, остварује идејну завршеност и разоткрива скривени смисао. Јаковљева мржња према брату Матеју у приповеци „Убиство“ (Убийство) завршава се зверским убиством Матеја. Важно је да Јакова не ужасава његов поступак толико, колико „окрвављени кувани кромпир“: „Али ништа није било тако страшно Јакову, као окрвављени кувани кромпир на који се он бојао да нагази, ...“ (Чехов 1977, IX: 154). Кромпир на уљу, који је Матеј јео посног дана, постао је симбол идејног разилажења двојице браће. Чини се да тек сада, гледајући у кромпир, пошкропљен крвљу убијеног брата, Јаков спознаје сав ужас свога злочина и ништавност његовог разлога. На тај начин наведени детаљ представља безумну опседнутост неком идејом која може да кошта људског живота.

У „Причи непознатог човека“ (Рассказ неизвестного человека) за богатим ручком, донетим из ресторана, Зинаида Фјодоровна окривљује собарицу Пољу за крађу и излази у сузама, тако да није ни дотакла ручак: „И ко зна зашто сада сва ова раскош из ресторана, која је била на столу, учинила ми се сиромашном, лоповском, која личи на Пољу. Најјаднији и криминални изглед имале су две пирошке на тањирићу. 'Данас ће нас вратити назад у ресторан, - као да су говориле оне, - а сутра ће нас опет дати за ручак неком чиновнику или познатој певачици" “(Чехов 1977, VIII: 175).

У пирошкама је симболички оваплоћена сва неискреност ситуације у којој се нашла Зинаида Фјодоровна пошто је свој живот везала за Орлова. Она себе обмањује, надајући се да је он воли, док он обмањује њу и не говори о својим стварним намерама. Собарица краде њене ствари. Неочекивани симбол у виду „криминалних пирошки“ представља концентрат владајуће лажи и лицемерства. И пирошке су приморане „да обмањују“, када их служе по неколико пута различитим људима тврдећи да су свеже. Композицијски ова епизода у новели претходи кобном разочарењу Зинаиде Фјодоровне у Орлова, када она сазнаје истину о његовом односу према њој.

Хтели бисмо да поменемо још један детаљ, који симболише створену ситуацију у приповеци „Непријатност“ (Неприятность). Када доктор Овчиников пише надређенима писмо-жалбу на свог помоћника-пијаницу, кроз прозор посматра следећи призор: „... једно паче је нашло на путу неко црево, почело да се гуши и пиштећи дигло је узбуну; друго је притрчало њему, извадило 
је из његовог кљуна црево и такође се почело давити...“(Чехов 1977, VII: 145). Чинило би се да ова невина епизода свакодневице јесте сасвим случајна, али будући да се у новели појављује после непријатног сукоба између доктора и помоћника, добија сасвим други уметнички задатак. Даљи догађаји у приповеци, повезани са разјашњавањем инцидента који се десио, омогућују да се епизода са пачићима доживи као карактеристика описане ситуације: нико никоме не може да помогне. Свако је на свој начин несрећан због функције коју обавља и „гуши се“, зато што је све повезано на основу родбинско-пријатељских односа, који не дозвољавају да се појави строгост и да се предузму радикалне мере. Ако помогнем теби, онда ћу се сам угушити од бесконачног низа непријатности, као оно паче са цревом.

Оригиналност Чеховљевих симбола састоји се у томе што помоћу обичног предмета, ствари он може разоткривати све могуће планове стварности која га окружује. Његови симболи су необични и многострани. Симболички детаљи у Чеховљевим новелама оригинално и, у исти мах, неочекивано одражавају значења неког појма или појаве, приказујући неку њихову страну, где се, као у огледалу, одражавају различите емоције, душевна проживљавања, суштински смисао ситуације, идејни садржај целог приповедања. Као резултат таквих разноврсних синтеза, добијамо дубље значење неке појаве, посматрајући рађање њених нових смислова у пишчевим делима. Чеховљеви симболи, као суштински уметничко-естетски садржај слике, стварају подтекст његових дела и разоткривају истински смисао написаног. Како запажа В. Набоков: „Чехов је први од писаца доделио подтексту битну улогу у преносу конкретног смисла“ (Набоков 1999: 326). Понекад се симболички детаљи појављују једанпут у новели, да би окарактерисали, одредили ситуацију, као пирошке у „Причи непознатог човека“ или окрвављени кувани кромпир у „Убиству“. Чешће симболички детаљ постаје лајтмотив, као кишобран у приповеци „Три године“, или врба и виолина у „Ротшилдовој виолини“.

\section{Цитирана литература}

Белкин, Абрам А. Читая Достоевского и Чехова. Статьи и разборы. Москва: Художественная литература, 1973.

[Belkin, Abram A. Čitaâ Dostoevskogo i Čehova. Stat'i i razbory. Moskva: Hudožestvennaâ literatura, 1973]

Белый, Андрей. «Чехов». [В:] И. Н. Сухих (ред.) А. П. Чехов: Pro et contra. СанктПетербург: РХГИ, 2002.

[Belyj, Andrej. «Čehov». [V:] I. N. Suhih (red.) A. P. Čehov: Pro et contra. SanktPeterburg: RHGI, 2002]

Громов, Леонид П. Реализм А. П. Чехова второй половины 80-х годов. Ростов-наДону: Ростовское книжное издательство, 1958.

[Gromov, Leonid P. Realizm A. P. Chekhova vtoroǐ poloviny 80-kh godov. Rostov-naDonu: Rostovskoe knizhnoe izdatel'stvo, 1958]

Замятин, Евгений И. Лица. Нью-Йорк: Издательство имени Чехова, 1955.

[Zamiätin, Evgeniı̌ I. Litşa. N'iûu-Ǐork: Izdatel'stvo imeni Chekhova, 1955] 
Лосев, Алексей Ф. Проблема символа и реалистическое искусство. Москва: Искусство, 1995.

[Losev, AleksejF. Problema simvola i realističeskoe iskusstvo. Moskva: Iskusstvo, 1995]

Лотман, Юрий М. «Символ в системе культуры». [В:] Ю. М. Лотман (ред.) Избранные статьи: Т. 1. Таллин: Александр, 1992, 191-199.

[Lotman, ÛrijM. «Simvol v sistemekul'tury». [V:] Û. M. Lotman (red.) Izbrannye stat'i: T. 1. Tallin: Aleksandr, 1992, 191-199]

Лотман, Юрий М. Внутри мыслящих миров. Человек - текст - семиосфера - история. Москва: Языки русской культуры, 1996.

[Lotman, Ûrij M. Vnutri myslâŝih mirov. Čelovek - tekst - semiosfera - istoriâ. Moskva: Âzyki russkojkul'tury, 1996]

Минералова, Ирина Г. Проза Чехова и проблема реалистического символа. Автореферат на соискание ученой степени кандидата филологических наук. Специальность 10.01.01. - русская литература. Москва, 1985.

[Mineralova, Irina G. Proza Čehova i problema realističeskogo simvola. Avtoreferat na soiskanie učenoj stepeni kandidata filologičeskih nauk. Special'nost' 10.01.01. russkaâ literatura. Moskva, 1985]

Мирский, Дмитрий П. «История русской литературы с древнейших времен по 1925 год. Т. 2: Современная русская литература (1881-1925)», Открытый текст, электронное периодическое издание <http://opentextnn.ru/man/svjatopolk-mirskij-d-sistorija-russkoj-literatury-s-drevnejshih-vremen-po-1925-god-t-2/> 26.07.2020.

[Mirskiŭ, Dmitriǔ P. «Istoriiâa russkoî literatury s drevneĭshikh vremen po 1925 god. T. 2: Sovremennaiā russkaiā literatura (1881 - 1925)», Otkryty̌̌ tekst, èlektronnoe periodicheskoe izdanie <http://opentextnn.ru/man/svjatopolk-mirskij-d-s-istorijarusskoj-literatury-s-drevnejshih-vremen-po-1925-god-t-2/ > 26.07.2020]

Набоков, Владимир В. Лекции по русской литературе. Москва: Издательство Независимая газета, 1999.

[Nabokov, Vladimir V. Lekcii po russkoj literature. Moskva: Izdatel'stvo Nezavisimaâ gazeta, 1999]

Фарыно, Ежи. Введение в литературоведение. Санкт-Петербург: Издательство РГПУ им. А.И. Герцена, 2004.

[Faryno, Eži. Vvedenie v literaturovedenie. Sankt-Peterburg: Izdatel'stvo RGPUim. A.I. Gercena, 2004]

Чудаков, Александр П. Поэтика Чехова. Москва: Наука, 1971.

[Čudakov, Aleksandr P. Poètika Čehova. Moskva: Nauka, 1971]

\section{Извори}

Чехов, Антон П. Полное собрание сочинений и писем в тридцати томах. Сочинения в восемнадцати томах. Том седьмой (1888-1891). Москва: Наука, 1977.

[Čehov, Anton P. Polnoe sobranie sočinenij i pisem v tridcati tomah. Sočineniâ v vosemnadcati tomah. Tom sed'moj (1888-1891). Moskva: Nauka, 1977]

Чехов, Антон П. Полное собрание сочинений и писем в тридцати томах. Сочинения в восемнадцати томах. Том восьмой (1892-1894). Москва: Наука, 1977.

[Čehov, Anton P. Polnoe sobranie sočinenij i pisem v tridcatitomah. Sočineniâ v vosemnadcati tomah. Tom vos'moj (1892-1894). Moskva: Nauka, 1977] 
Чехов, Антон П. Полное собрание сочинений и писем в тридцати томах. Сочинения в восемнадцати томах. Том девятый (1894-1897). Москва: Наука, 1977.

[Čehov, Anton P. Polnoe sobranie sočinenij i pisem v tridcati tomah. Sočineniâ v vosemnadcati tomah. Tom devâtyj (1894-1897). Moskva: Nauka, 1977]

Галина Лукич

\section{СИМВОЛИЧЕСКИЕ ДЕТАЛИ В НЕКОТОРЫХ РАССКАЗАХ А. П. ЧЕХОВА}

\section{Резюме}

Средства образной выразительности имеют большой удельный вес в художественной системе А. П. Чехова. В создании индивидуально-авторских символов проявляется оригинальность писательского стиля Чехова. Ассоциативный образ возникает обычно в результате неожиданного сочетания далеких понятий. Символические детали Чехова отличаются своей нейтральностью, ими могут стать такие предметы, как зонтик, верба, скрипка, синяя материя. Обыденные предметы в художественной системе Чехова совершенно неожиданно наполняются глубоким идейным смыслом и предстают перед читателем в своем высшем проявлении, а в «бесконечном ряде частностей и единичностей» (Лосев) раскрывают сущность описываемого явления. Система ассоциаций, порождаемая символической деталью, формирует у читателя новые картины и образы, которые, накладываясь на прочитанный текст, помогают раскрыть замысел автора. Чтобы проникнуть в суть символической детали, нужно внимательно проследить за её композиционным включением в текст повествования: с чем связано появление той или иной детали, какие эмоции героев произведения её сопровождают.

Ключевые слова: Чехов, символ, сиволическая деталь, ассоциативный образ. 